\title{
Evaluation of TEAM Leafy Spurge Project
}

\author{
Nancy M. Hodur, ${ }^{1}$ F. Larry Leistritz, ${ }^{2}$ and Dean A. Bangsund ${ }^{3}$ \\ Authors are ${ }^{1}$ Research Scientist, ${ }^{2}$ Professor, and ${ }^{3}$ Research Scientist, Department of Agribusiness and \\ Applied Economics, North Dakota State University, Fargo, ND 58105.
}

\begin{abstract}
Leafy spurge (Euphorbia esula L.) is an exotic, noxious, perennial weed which is widely established in the north central United States and is an especially serious problem in the northern Great Plains. In 1997, the Agricultural Research Service and Animal and Plant Health Inspection Service, U.S. Department of Agriculture, initiated a major Integrated Pest Management (IPM) research and demonstration project to develop and demonstrate ecologically based IPM strategies that can produce effective, affordable leafy spurge control. In 1998 and 1999, a survey of ranchers, local decision makers, and public land managers was conducted to evaluate managerial, institutional, and social factors that might affect the rate and extent of implementation of various control strategies. In 2001, a second survey of the same ranchers, local decision makers, and public land managers was conducted to 1) assess any changes in land managers' perceptions of weed problems, control alternatives, and related issues and 2) evaluate the impact of The Ecological Area-wide Management (TEAM) Leafy Spurge (TLS) project on the respondents' weed control practices. Findings from the first survey identified a number of constraints limiting land managers' ability to utilize available control techniques to manage leafy spurge infestations. The TLS project used a variety of tools and communication strategies, such as presentations at local meetings, demonstration plots, and field days, to communicate and demonstrate weed control strategies and address the impediments to leafy spurge control identified in the first survey. Findings from the second survey indicated TLS efforts had effectively addressed many of the constraints to leafy spurge control previously reported by landowners and land managers.
\end{abstract}

\section{Resumen}

"Leafy spurge" (Euphorbia esula L.) es un maleza exotica, nociva y perenne, la cual esta ampliamente establecida en la región norte centro de Estados Unidos de América y es un problema especialemente serio en las Grandes Planices del Norte. En 1977, el Servicio de Investigación Agrícola y el Servicio de Inspección Sanitario de Plantas y Animales del Departamento de Agricultura de los Estados Unidos de América iniciaron un importante investigación sobre el Manejo Integrado de Plagas (IPM) y un proyecto de demostración para desarrollar y demostrar estrategias de IPM con base ecológica que puedan producir un control del "Leafy spurge" efectivo y económicamente viable. En 1998 y 1999 se realizó una entrevista entre investigadores, tomadores de decisiones locales, y manejadores de tierras públicas para evaluar los factores de manejo, institucionales, y sociales que pudieran afectar la tasa y cantidad de implementación de varias estrategias de control. En el 2001, un segunda entrevista a los mismos investigadores, tomadores de decisiones locales, y manejadores de tierras publicas se condujo para 1) evaluar cualquier cambio en las percepciones de los manejadores de tierras respecto a los problemas de maleza, alternativas de control y problemas relacionados y 2) evaluar el impacto del proyecto TEAM "Leafy spurge" (TLS) en las practicas de control de la maleza de los entrevistados. Los hallazgos de la primer entrevista identificaron un número de obstaculos que limitaban la capacidad de los manejadores de tierras para utilizar las técnicas de control disponibles para manejar las infestaciones de "Leafy spurge." El proyecto TLS uso una variedad de hereramientas y estrategias de comunicación, tales como presentaciones en reuniones locales, parcelas de demostración, y días de campo demostrativos para comunicar y demostrar las estrategias de controla abordar los impedimentos del control de "Leafy spurge" identificados en la primer entrevista. Los hallazgos de la segunda entrevista indicaron que los esfuerzos del TLS habían abordado efectivamente muchas de las limitantes para controlar el "Leafy spurge" previamente reportadas por los propietarios y manejadores de las tierras.

Key Words: noxious weeds, weed management, rancher opinion, survey, biocontrol, IPM (integrated pest management)

\section{INTRODUCTION}

Leafy spurge (Euphorbia esula L.) is an exotic, noxious, perennial weed which is widely established in the north central United States and is an especially serious problem in the northern Great Plains (Bangsund et al. 1999). Leafy spurge

Correspondence: Nancy M. Hodur, Agribusiness and Applied Economics, North Dakota State University, P0 Box 5636, Fargo, ND 58105-5636. Email: nhodur@ndsuext. nodak.edu

Manuscript received 11 November 2005; manuscript accepted 11 June 2006. infests untilled land and reduces livestock carrying capacity on rangeland, alters the appearance of the landscape, and degrades wildlife habitat. Leafy spurge infests more than 5 million acres in 15 states and 6 Canadian provinces. The resulting economic impacts are substantial, estimated at $\$ 130$ million annually in North Dakota, South Dakota, Montana, and Wyoming alone (Leistritz et al. 2004).

The unique physiological characteristics of leafy spurge make it difficult to control. No single control method can eradicate established infestations, but expansion can be controlled with a combination of biological and chemical control in an integrated pest management (IPM) framework (Lym and 
Messersmith 1994; Lym and Zollinger 1995; Lym et al. 1997; Lym 2005). To address the lack of comprehensive information on IPM strategies available to landowners and land managers, in 1997 the Agricultural Research Service and the Animal and Plant Health Inspection Service, U.S. Department of Agriculture, initiated a major IPM research and demonstration project, TEAM Leafy Spurge, to develop and communicate ecological, economical, and sustainable leafy spurge management techniques to land managers. The primary goal of TEAM Leafy Spurge (TLS) was to develop and demonstrate ecologically based IPM strategies that can produce effective, affordable leafy spurge control. The effort involved a wide range of Federal, state, and local agencies; universities; and private organizations. TLS coordinated the efforts of all participants and divided the project into four major components: Operations, Assessment and Inventory, Program Management, and Supporting Research and Demonstrations (Schmidt 1998). The TLS project study area was the multicounty Little Missouri River Drainage in southwestern North Dakota, southeastern Montana, northeastern Wyoming, and northwestern South Dakota. Demonstration sites were located in Billings and Golden Valley counties, North Dakota; Carter County, Montana; and Harding County, South Dakota.

One element of the Supporting Research and Demonstration component was an examination of the socio-economic factors affecting leafy spurge control. In one of the first phases of the overall TLS project and phase one of the socio-economic component of the study, ranchers, local decision makers, and public land managers in the TLS project area were surveyed to evaluate managerial, institutional, and social factors that might affect the rate and extent of implementation of various control strategies (Sell et al. 1998a, 1998b, 1999a, 1999b). In 2001, near the conclusion of the TLS project, a second survey of the same group of ranchers, local decision makers, and public land managers was conducted to 1) assess any changes in land managers' perceptions of weed problems, control alternatives, and related issues and 2) evaluate the impact of the TLS project on respondents' perceptions and/or weed control practices.

A number of authors have examined ranchers' adoption of various management innovations and/or evaluated the effectiveness of extension/outreach programs. Many of the papers focused on characteristics of adopters rather than program evaluation. This study examines changes in respondent perceptions and use of various weed control practices to gauge the program's success in achieving program goals. Didier and Brunson (2004) interviewed Utah ranchers who had been identified as innovators. They found that these ranchers were generally ranching full-time, were primarily dependent on ranch income, and indicated a strong, long-term commitment to ranching. Rowan and White (1994) found that Texas ranchers who treated their pastures for weeds and brush also received higher than average percentages of their family income from livestock sales and lower percentages from off-ranch employment. Coppock and Birkenfeld (1999) found the use of 26 different range and livestock management practices differed substantially among Utah ranch operators, with larger ranch size and higher levels of operator education and income being associated with using more practices. Peterson and Coppock (2001) also surveyed Utah ranchers to determine their management approach. About $80 \%$ of respondents were passive (i.e., not active) managers; the most common reasons for a passive management style were imminent retirement and economic constraints (e.g., low cattle prices, low returns on ranch investments). Kreuter et al. (2001) surveyed Texas county extension agents to evaluate the success of a research-extension program on brush management. The agents reported that the new program had generated a high level of producer interest and felt that the main reasons for this interest were its relatively low cost, ease of application, safety/selectivity, and effectiveness/predictability. Fernandez-Gimenez et al. (2005) evaluated Arizona Cooperative Extension Service's Rangeland Monitoring Program, using focus groups and a mail survey of grazing permittees and natural resource agency employees. They found that the extension program has been effective in reaching a large part of its target audience, although overall monitoring rates remain low.

This article reports the findings associated with landowners' and land managers' perceptions regarding leafy spurge control and an assessment of the effect of the TLS project on respondents' weed control practices. The survey also examined respondent's perceptions of other issues and problems faced by livestock grazing operations, perceptions regarding weeds posing the greatest problems for grazing operations, and the type of information respondents were interested in receiving and in what form they would prefer to receive it. Survey results not reported in this paper were reported in Hodur et al. (2002a, $2003 \mathrm{~b})$. Several other projects also were undertaken as part of the socio-economic component, including an assessment of the economics of controlling leafy spurge with sheep grazing (Bangsund et al. 2001) and an assessment of the feasibility of a sheep cooperative for leafy spurge control (Sell et al. 2000).

\section{METHODS}

\section{Survey}

Phase one of the socio-economic component of TLS consisted of focus group and personal interviews and a written mail-in questionnaire of landowners, land managers, and local decision makers. Three distinct groups were identified as stakeholders: private land owners, public land managers, and local decision makers. Private land owners consisted of farmers and ranchers with grazing operations in the study area. The public land managers were divided into two groups: public land managers of grazing land (PLMG) and public land managers of nongrazing land (PLMNG), as land managers' perceptions and goals often differ depending on primary land use. Agencies surveyed as part of the public land managers of grazing land included U.S. Department of Interior (USDI)-Bureau of Land Management, U.S. Department of Agriculture-Forest Service, USDI Bureau of Indian Affairs, North Dakota Department of Corrections, and the State land departments of North Dakota, South Dakota, Montana, and Wyoming. Agencies surveyed in the public land manager, nongrazing land category included USDI National Park Service (Theodore Roosevelt National Park, Devils Tower National Monument); USDI Bureau of Reclamation, and Fish and Wildlife Service; and North Dakota, South Dakota, Wyoming, and Montana departments of Game and Fish Management and Departments of Transportation. Local decision makers, defined as individuals that make or 
influence public weed management policy, were the final group of stakeholders surveyed and included county weed board members, state legislators, county commissioners, and township board members.

Focus group discussions and personal interviews with representatives of each of the groups were used to help identify and clarify key issues related to leafy spurge control. Three focus group discussions were held with ranchers and local decision makers. One focus group was made up of ranchers only, and a second was comprised only of local decision makers. A third focus group included both ranchers and local decision makers, as logistics precluded conducting separate sessions for each. Focus group participants were selected based on recommendations from university extension and research personnel in each state, with the aim of involving persons with interest and experience in weed management issues. Each focus group was asked to consider factors that limit land managers' ability to effectively control leafy spurge (e.g., labor availability, limitations of existing controls). Personal interviews were conducted with public land managers from the agencies listed previously, as well as with a number of local decision makers (county weed board supervisors, county extension agents) in each state. Most of the personal interviews were conducted face-to-face, except in a few cases where distance and scheduling required telephone interviews. Personal interviews also consisted of a discussion of factors and issues that limit landowners' and land managers' ability to effectively control leafy spurge. Findings from the focus group and personal interviews were central to the development of the written questionnaire (Sell et al. 2000). In 1998, the written questionnaire was mailed to 459 randomly selected ranchers (approximately one-third of the farmers and ranchers in the study area), 56 local decision makers, 29 public grazing land managers, and 21 public nongrazing land managers in Golden Valley and Billings Counties in North Dakota; Carter County, Montana; Crook County, Wyoming; and Harding County, South Dakota. (Only those farm/ranch operations with livestock grazing operations were included in the rancher sample [i.e., those farm operations with no livestock were excluded from the sample]). Rancher mailing addresses were obtained from Intertec Publishing. Although the rancher survey was a simple random sample, all persons/offices meeting the criteria for local decision makers, public grazing land managers, and public nongrazing land managers in the study area received questionnaires. A second mailing to ranchers and local decision makers and a follow-up phone call to public land managers resulted in response rates of $41 \%$ for ranchers, $68 \%$ for local decision makers, $83 \%$ for public grazing land managers, and $86 \%$ for public nongrazing land managers. In 1999, the study area was expanded and the same questionnaire was mailed to 476 ranchers (selected in the same manner as in 1998) and 45 local decision makers in 4 additional counties: Slope and Bowman Counties in North Dakota and Wibaux and Fallon Counties in Montana. No additional public land managers were surveyed. Response rates in 1999 were $32 \%$ for ranchers and $49 \%$ for local decision makers. Overall, a combined total of 935 ranchers and 101 local decision makers were surveyed in 1998 and 1999 with a response rate of $36 \%$ for ranchers and $59 \%$ for local decision makers. The results of the 1998 and
1999 surveys (Sell et al. 1998a, 1998b, 1999a, 1999b) were combined in this report and are treated as one survey.

\section{Survey}

The last phase of the socio-economic component was completed in 2001, near the end of the TLS project. Another questionnaire was mailed to the same sample of ranchers, local leaders, and public land managers surveyed by Sell et al. (1998a, 1999a). Because of personnel changes, individual respondents to the local decision maker and public land manager survey were not identical. However, questionnaires were delivered to individuals holding the same positions as in the 1998-1999 survey. Questionnaires were mailed to 927 ranchers, 97 local decision makers, 37 PLMG, and 21 PLMNG in July 2001. One follow-up mailing resulted in response rates of $35 \%, 50 \%, 67 \%$, and $76 \%$, respectively.

\section{Statistical Analysis}

Some sections of the 1998-1999 and 2001 questionnaires were identical, so responses between study periods could be compared to identify any changes in respondent perceptions, one of the objectives of the socio-economic component of TLS. A paired $t$ test (SAS Institute 2004) and Fisher's Exact test (Le 1948), both at a $95 \%$ confidence interval, tested for differences in responses. The paired $t$ test was used to compare the means of attitude and perception questions where responses were measured with a 3-point Likert scale (where 1 was "not a problem," 2 was "minor problem," and 3 was "major problem"). Those questions also offered respondents a "don't know" option, which was not included in the calculation of the mean (average score). The Fisher's exact test was used to compare responses of unordered questions related to leafy spurge control methods. Comparisons were made between study years for each study group. Comparative analysis was limited to questions that were present in both the 1998-1999 and 2001 study.

\section{RESULTS}

\section{Focus Group and Personal Interviews, 1998}

Sell et al. (2000) reported focus group and personal interview findings. Ranchers overall were generally discouraged by their lack of success controlling leafy spurge. They perceived they were "losing the battle" against leafy spurge despite committing substantial resources and, in some instances, were unwilling to invest any additional resources in control efforts. The inability to eradicate leafy spurge left many ranchers skeptical of alternate or new control methods. Ranchers viewed leafy spurge control as a matter of eradication, an unrealistic expectation, rather than that of a long-term management issue.

Absentee landowners' indifference and a lack of awareness of weed problems also contributed to ranch operators' frustration. In many cases, land rents did not reflect the decreased carrying capacity of leafy spurge-infested rangeland. As a result, there was no incentive for absentee land owners to control leafy spurge.

Labor and time were also mentioned as limiting factors, particularly with respect to scouting and treating new or smaller patches of leafy spurge. Other limiting factors included the cost of herbicides and the general lack of information and expertise 
Table 1. Demographic characteristics, ranchers, 2001 and 1998-1999.

\begin{tabular}{lc}
\hline Item & Percent \\
\hline Age & \\
25 years or less & 1.5 \\
25 to 45 years & 32.8 \\
46 to 65 years & 45.6 \\
66 years or more & 20.1 \\
Average age & 53 \\
(no.) & $(329)$ \\
Education & \\
High school diploma or some high school & 56.5 \\
Vo-tech or 2-year degree & 21.6 \\
Bachelors or advanced degree & 21.9 \\
(no.) & $(324)$ \\
Have spurge on farm or ranch & 52.2 \\
(no.) & $(580)$ \\
2001 respondents & 55.7 \\
(no.) & $(262)$ \\
1998-99 respondent & 49.4 \\
(no.) & $(318)$ \\
Percent of gross farm income from grazing livestock & \\
Less than 50 percent & \\
51 to 70 percent & \\
71 to 80 percent & 54.6 \\
81 percent or more & $(544)$ \\
(no.) & \\
\hline
\end{tabular}

regarding alternate control methods, specifically biological control with insects. Ranchers indicated they did not know where to obtain insects, or where or when to release the insects. Overall, ranchers' perceptions were colored with a general sense of frustration over the inability to eradicate leafy spurge, despite considerable investments of time and money.

Local decision makers were more cognizant of the need for a long-term management plan, but financial constraints limited their efforts. A seemingly ever-expanding leafy spurge problem coupled with less financial support from the state was not only a source of frustration but also a serious impediment to longterm control efforts. Local leaders also cited the shortage of certified applicators and the cost of using certified applicators. Lastly, it was observed that herbicides often were being applied inconsistently and at rates two to three times higher than recommended. The improper application of herbicides served only to increase the cost of control per acre and reduce the number acres treated, further exacerbating existing financial constraints.

Public land managers' perspectives differed slightly from the other study groups. Rotating leadership and changing policies associated with administration and personnel changes were cited by public land managers as a major problem limiting leafy spurge control efforts. Inconsistent policies, coupled with a general lack of resources, made leafy spurge control on public lands difficult. Remote or inaccessible terrain and inadequate weed inventory and monitoring programs also made leafy spurge control on public lands difficult.
Whereas eliminating all constraints to various control methods is not likely (e.g., environmental constraints such as rough or inaccessible terrain), the focus group interviews identified several opportunities for improved management of leafy spurge. For example, financial and time/labor constraints were mentioned by all groups as a limitation to controlling leafy spurge. Although financial limitations can seem insurmountable, scarce resources could be maximized by implementing control measures in the most efficient and effective manner possible in order to achieve optimal results. The focus group and personal interviews provided an initial examination of land managers' perspectives regarding leafy spurge control practices and impediments to control. These issues were further examined in the subsequent written surveys. Focus group and personal interview findings also were considered in the design of outreach/educational materials.

\section{SURVEY RESULTS 1998-1999 AND 2001}

\section{Rancher Respondent Demographics}

The average age of rancher respondents was 53 years and the largest group of respondents $(46 \%)$ was the 46- to 65 -year age group (Table 1). Education was fairly evenly split between those with some high school or a high school diploma $(56 \%)$ and those with a two-year or vo-tech or college degree $(44 \%)$. Fifty-six percent of respondents in 2001 reported the presence of leafy spurge on their farm or ranch, compared to $49 \%$ of respondents in the 1998-1999 survey. Livestock grazing was the primary source of income for most respondents, with $78 \%$ of respondents reporting more than $50 \%$ of gross farm income from grazing livestock and $54 \%$ that reported $81 \%$ or more of gross farm income from grazing livestock.

\section{Weed Control Practices}

Herbicide use was widespread. Ninety-three percent of ranchers, $95 \%$ of PLMG, and $100 \%$ of PLMNG used herbicides to control leafy spurge (Table 2). These figures were roughly unchanged from the 1998-1999 survey with no significant differences among ranchers (Fisher's exact test $P \leq 0.05$ ). Differences between study periods in the other study groups were not tested for statistical significance because of the small sample sizes. Use of biological control agents was also prevalent with over half of the ranchers $(53 \%), 75 \%$ of the PLMNG, and $95 \%$ of the PLMG respondents using biological control agents, again roughly the same as the 1998-1999 survey. Far fewer respondents used sheep or goat grazing or tillage and reseeding with competing grasses, with the exception of PLMG. Roughly 3 of 4 PLMG agencies used sheep or goat grazing to control leafy spurge. The IPM concept (using at least two of the stated control methods: herbicides, biological control agents, sheep or goat grazing, or tillage and/or reseeding) appeared to have widespread acceptance, as $51 \%$ of ranchers, $75 \%$ of PLMNG, and $100 \%$ of PLMG were currently using this approach. Because IPM was a concept introduced by TLS after the 1998-1999 survey, no comparative data for IPM were available.

Previous research (Rowan and White 1994; Kreuter et al. 2001; Peterson and Coppock 2001; Didier and Brunson 2004) reported adoption of management practices varied depending on 
Table 2. Use of selected practices to control leafy spurge, ranchers and public land managers, 2001 and 1998-1999.

\begin{tabular}{|c|c|c|c|c|c|c|}
\hline \multirow[b]{2}{*}{ Control practice } & \multicolumn{2}{|c|}{ Ranchers } & \multicolumn{2}{|c|}{$\begin{array}{c}\text { Public land managers, } \\
\text { grazing land }\end{array}$} & \multicolumn{2}{|c|}{$\begin{array}{c}\text { Public land managers, } \\
\text { nongrazing land }\end{array}$} \\
\hline & 2001 & $1998-1999^{2}$ & 2001 & $1998^{1,2}$ & 2001 & $1998^{1,2}$ \\
\hline & ------- & $------\cdot$ & cent cu & control & $-\cdots-\cdot-\cdot$ & -------. \\
\hline Herbicides & 93.0 & 97.4 & 94.7 & 100.0 & 100.0 & 100.0 \\
\hline Biological control & 52.9 & 47.2 & 94.7 & 95.2 & 75.0 & 71.4 \\
\hline Sheep or goat grazing & 17.8 & 25.7 & 73.7 & 83.3 & 12.5 & 37.5 \\
\hline Tillage and reseeding with competing grasses & 27.0 & 13.3 & 21.1 & 10.5 & 18.8 & 25.0 \\
\hline Integrated Pest Management (IPM) & 50.8 & $\mathrm{n} / \mathrm{a}$ & 100.0 & $\mathrm{n} / \mathrm{a}$ & 75.0 & $\mathrm{n} / \mathrm{a}$ \\
\hline
\end{tabular}

${ }^{1}$ Average number of responses per control practice.

${ }^{2} 1998$ and 1999 questionnaire stated the question: "have you used control method in the past."

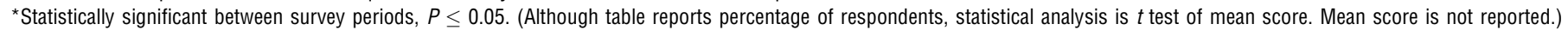

various demographic and ranch characteristics such as age, income, education, and percentage of gross income from farm and ranch activities. Use of herbicides, biological control, sheep or goat grazing, tillage, and IPM practices were examined by respondents' age, education, and percentage of gross income from grazing to identify if such linkages were present in this study. Respondent age, education, or percentage of gross income from ranching was not found to be a factor in respondents' use of a particular control practice. No statistically significant differences were identified. Differences in the study population might address issues related to adoption of control practices based on demographic characteristics. For example in this study, $70 \%$ of ranchers received more than $70 \%$ of their gross income from grazing livestock compared to only $30 \%$ in the Rowan and White study (1994). Further, Peterson and Coppock (2001) found that $37 \%$ of ranchers were 66 years or older and $43 \%$ of respondents cited imminent retirement/poor health as constraints to their management plans. In this study, only $20 \%$ of respondents were age 66 or older, and nearly $60 \%$ were age 50 or less. Whereas characteristics of respondents might in some cases be a factor in use and adoption of management practices, no such relationship was found in this study.

\section{Evaluation of TEAM Leafy Spurge Project}

Because outreach efforts were a major component of the TLS program, respondents were asked a series of questions designed to gauge awareness of the program. Overall, awareness of the program was quite high. A majority of PLMG, LDM, and PLMNG were aware of the program $(90 \%, 85 \%$, and $66 \%$, respectively [data not shown]). Nearly half of the ranchers surveyed also indicated they were aware of the program (data not shown). The questionnaire also measured respondents' participation in a number of TLS events (Table 3). In addition to two Spurgefest field tours in Medora, North Dakota, in 1999 and 2001, TLS sponsored numerous events and demonstration

Table 3. Attendance and ratings of TEAM Leafy Spurge events: ranchers, local decision makers, and public land managers, 2001.

\begin{tabular}{|c|c|c|c|c|c|c|c|c|}
\hline & \multicolumn{2}{|c|}{ Ranchers } & \multicolumn{2}{|c|}{$\begin{array}{l}\text { Local decision } \\
\text { makers }\end{array}$} & \multicolumn{2}{|c|}{$\begin{array}{c}\text { Public land } \\
\text { managers, grazing }\end{array}$} & \multicolumn{2}{|c|}{$\begin{array}{c}\text { Public land } \\
\text { managers, nongrazing }\end{array}$} \\
\hline & $\begin{array}{l}\text { Percent of } \\
\text { respondents }\end{array}$ & $\begin{array}{l}\text { Average } \\
\text { score }^{1}\end{array}$ & $\begin{array}{l}\text { Percent of } \\
\text { respondents }\end{array}$ & $\begin{array}{l}\text { Average } \\
\text { score }^{1}\end{array}$ & $\begin{array}{l}\text { Percent of } \\
\text { respondents }\end{array}$ & $\begin{array}{l}\text { Average } \\
\text { score }^{1}\end{array}$ & $\begin{array}{l}\text { Percent of } \\
\text { respondents }\end{array}$ & $\begin{array}{l}\text { Average } \\
\text { score }^{1}\end{array}$ \\
\hline \multicolumn{9}{|l|}{ Attendance TLS event or meeting: ${ }^{2}$} \\
\hline 1999 Spurgefest & 6.7 & 5.6 & 36.6 & 5.9 & 30.0 & 6.3 & 18.8 & 6.7 \\
\hline 2001 Spurgefest & 2.6 & 6.2 & 21.6 & 5.6 & 35.0 & 6.9 & 23.5 & 6.7 \\
\hline $\begin{array}{l}\text { TEAM Leafy Spurge presentation at } \\
\text { another event or meeting }\end{array}$ & 16.3 & 5.9 & 46.0 & 5.4 & 31.6 & 5.4 & 29.4 & 6.3 \\
\hline Any Spurgefest event or meeting & 21.2 & 5.8 & 60.8 & 5.7 & 60.0 & 6.3 & 29.4 & 6.5 \\
\hline (no.) & $(240)$ & $(19)$ & $(47)$ & (13) & (20) & (6) & $(17)$ & (6) \\
\hline $\begin{array}{l}\text { Visited at least one TLS Demonstration site: }{ }^{2} \\
\text { (no.) }\end{array}$ & $\begin{array}{l}23.3 \\
(248)\end{array}$ & $\begin{array}{c}5.4 \\
(16)\end{array}$ & $\begin{array}{l}61.7 \\
(42)\end{array}$ & $\begin{array}{l}5.6 \\
(7)\end{array}$ & $\begin{array}{l}52.6 \\
(18)\end{array}$ & $\begin{array}{l}6.6 \\
(3)\end{array}$ & $\begin{array}{l}23.5 \\
(17)\end{array}$ & $\begin{array}{l}6.2 \\
(1)\end{array}$ \\
\hline \multicolumn{9}{|l|}{$\begin{array}{l}\text { Visited at least one demonstration } \\
\text { site, attended at least one TLS event } \\
\text { or meeting, or received TLS }\end{array}$} \\
\hline brochures or other materials ${ }^{3}$ & 37.4 & 5.5 & 89.8 & 5.6 & 90.0 & 6.3 & 64.7 & 6.3 \\
\hline (no.) & $(270)$ & (258) & $(49)$ & $(154)$ & (20) & (85) & (17) & (44) \\
\hline
\end{tabular}

${ }^{1}$ Based on a scale of 1 to 7 , where 1 is poor and 7 is excellent.

${ }^{2}$ Average number of respondents for each event.

${ }^{3}$ Total number of respondents. 
sites, participated in many state and local meetings, produced numerous brochures and publications, developed a web site, and produced a CD. Respondent participation in events and use of TLS publications was very good. Ninety percent of the LDM and PLMG, $65 \%$ of PLMNG, and $37 \%$ of all ranchers attended at least one TLS event, were present for a TLS presentation at another event or meeting, visited at least one demonstration site, or used TLS outreach material such as brochures or the TLS web site. Seventy-six percent of ranchers that reported leafy spurge on their ranch attended at least one TLS event, were present at a TLS presentation at another event or meeting, visited at least one demonstration site, or used TLS outreach material (data not shown). Respondents rated events positively, with average scores ranging from 5.4 to 6.6 on a 7 -point scale $(1=$ poor and $7=$ excellent $)$. Clearly the TLS project was quite effective in reaching its target audience. In comparison, Fernandez-Gimenez et al. (2005) found that $70 \%$ of agency respondents and $42 \%$ of permittees (ranchers) reported receiving range monitoring information or services from cooperative Extension.

Responses to a series of general statements about the effectiveness of TLS were also very positive. Respondents were asked if they agree, disagree, or neither agree nor disagree. A majority of LDM (82\%), PLMG $(71 \%)$, and ranchers $(69 \%)$ agreed that the TLS project had been effective in demonstrating and communicating leafy spurge control options to ranchers and land managers. Fifty percent of PLMNG also agreed with this statement. A majority of respondents in all groups also agreed that project funding should be extended to continue research and education efforts. Further, $42 \%$ of ranchers, $82 \%$ of LDM, $76 \%$ of PLMG, and $57 \%$ of PLMNG indicated they or the agency or organization they represent had directly benefited from the project (data not shown).

\section{TEAM Leafy Spurge Influence on Weed Control Strategies}

Respondents in each of the four groups were asked how the TLS project had affected their weed control strategies (Tables 4-6). Responses were compared to similar questions in the 19981999 surveys to gauge changes in respondents' weed control strategies. Roughly half of the ranchers and LDM and one-third of the public land managers, both for grazing and nongrazing land, indicated TLS had influenced their use of herbicides (Table 4). Naturally, no comparison with 1998-1999 data could be made as it would be impossible for a new program (TLS) to have an impact on weed control strategies at its onset. Further, this is not inconsistent with findings that reported little change in the number of respondents using a given control practice between study periods. Using a control practice and acknowledging that TLS influenced how that practice would be used are not mutually exclusive. Among the ranchers, LDM, and PLMG who indicated that TLS had influenced their plans, most often respondents indicated they were planning to use herbicides to stop infestations from spreading and integrating herbicides with other control measures. Among those who said that TLS had not influenced their use of herbicides, the most common explanation was that they were already using herbicides $(74 \%$ of ranchers and $100 \%$ of PLMNG). When the reasons why TLS had not influenced respondents' plans were compared to the reasons why respondents were not using herbicides in the 19981999 surveys, respondents were generally less negative about constraints to using herbicides. For example, nearly $60 \%$ of ranchers cited environmental restrictions as an impediment to herbicide use in 1998-1999, while only $29 \%$ cited environmental restrictions as an impediment to herbicide use in the 2001 survey, a significant difference (Fisher's exact test $P \leq 0.05$ ). Further, significantly fewer ranchers and PLMNG indicated the reason TLS had not influenced their decision to use herbicides was that "infestations were too large and herbicides would be prohibitively expensive." Environmental restrictions were also cited by significantly fewer respondents in all groups as a reason why TLS had not influenced their weed control decisions (environmental restrictions were significant at $P \leq 0.10$, but not at $P \leq 0.05$ ) (Table 4).

Responses were similar when respondents were asked about TLS influence on biological control practices (Table 5). Over half of the respondents in each group indicated TLS had influenced their decision to use biological control agents with a majority of respondents in each group indicating they are now planning to use biological control as a result of TLS. Additionally, half of the ranchers and $81 \%$ of the LDM indicated they were now going to try biological control because insects are free and readily available.

Among those who indicated that TLS had not influenced their plans to use biological controls, frequent explanations were that "infestations were too small" or "infestations were not suitable for biological control." LDM were somewhat uncertain about the effectiveness of biological control, as $71 \%$ of LDM indicated they (and/or the people they represent) still were not convinced that biological control would work. As was the case with herbicides, many of the reasons cited in the 1998-1999 surveys as impediments to using biological control appear to be less prevalent. For example, in the 1998-1999 surveys, approximately one-third of the ranchers indicated they did not know how to use biological control agents or where to collect insects. In the 2001 survey, only $7 \%$ of ranchers indicated they were not using biological control agents because they did not know how to use them and only $4 \%$ said they did not know where to collect insects, both significant differences compared to responses in 1998-1999 (Fishers exact test $P \leq 0.05$ ) (Table 5). Significantly fewer ranchers also indicated that biological control with insects works too slowly, $18 \%$ in 2001 compared to $42 \%$ in $1998-1999$. The trend was similar in other study groups. Impediments related to the collection, acquisition, use, and effectiveness of biological control were cited less frequently in the 2001 survey than in the 1998-1999 survey. Significantly fewer LDM said they "do not know how to use biological control" (Table 5).

Fewer respondents indicated TLS had influenced their decisions to graze sheep for leafy spurge control than the other control methods. Seventeen percent of ranchers, 29\% of LDM, and $35 \%$ of PLMG indicated that TLS had influenced their plans to graze sheep to control leafy spurge (Table 6). Whereas TLS might not have influenced as many respondents' decisions to use sheep or goat grazing to control leafy spurge, respondents often indicated the reasons for not grazing sheep were factors outside their control. Ranchers, LDM, and PLMG all indicated TLS did not influence their decision because there were simply too many physical and logistical constraints (fencing, stock, and equipment) to sheep grazing. However, the $43 \%$ of ranchers that indicated there were too many constraints to sheep grazing in the 2001 survey represents 
Table 4. Impact of TEAM Leafy Spurge Project on weed control strategies using herbicides: ranchers, local decision makers, and public land managers, 2001, 1998, and 1999.

\begin{tabular}{|c|c|c|c|c|c|c|c|c|}
\hline & \multicolumn{2}{|c|}{ Ranchers } & \multicolumn{2}{|c|}{$\begin{array}{l}\text { Local decision } \\
\text { makers }\end{array}$} & \multicolumn{2}{|c|}{$\begin{array}{l}\text { Public land manager, } \\
\text { grazing land }\end{array}$} & \multicolumn{2}{|c|}{$\begin{array}{c}\text { Public land managers, } \\
\text { nongrazing land }\end{array}$} \\
\hline & $2001^{1}$ & $\overline{1998-1999^{2}}$ & $2001^{1}$ & $\overline{1998-1999^{2}}$ & $2001^{1}$ & $1998^{3}$ & $2001^{1}$ & $1998^{3}$ \\
\hline & --- & & & & cent--- & & & \\
\hline \multicolumn{9}{|l|}{$\begin{array}{l}\text { TEAM Leafy Spurge has influenced } \\
\text { my plans to use herbicides to }\end{array}$} \\
\hline control leafy spurge & 52.5 & $\mathrm{n} / \mathrm{a}$ & 45.0 & $\mathrm{n} / \mathrm{a}$ & 35.3 & $\mathrm{n} / \mathrm{a}$ & 35.3 & $\mathrm{n} / \mathrm{a}$ \\
\hline (no.) & $(80)$ & - & $(40)$ & - & (17) & - & $(12)$ & - \\
\hline \multicolumn{9}{|l|}{ If Yes: } \\
\hline \multicolumn{9}{|l|}{ Plan to use herbicides to stop } \\
\hline infestations from spreading & 60.0 & $\mathrm{n} / \mathrm{a}$ & 64.7 & $\mathrm{n} / \mathrm{a}$ & 83.3 & $\mathrm{n} / \mathrm{a}$ & 50.0 & $\mathrm{n} / \mathrm{a}$ \\
\hline \multicolumn{9}{|l|}{ Plan to integrate herbicides } \\
\hline with other control methods & 55.0 & $\mathrm{n} / \mathrm{a}$ & 88.2 & $\mathrm{n} / \mathrm{a}$ & 100.0 & $\mathrm{n} / \mathrm{a}$ & 50.0 & $\mathrm{n} / \mathrm{a}$ \\
\hline Plan to spray more of my leafy spurge & 12.5 & $\mathrm{n} / \mathrm{a}$ & 47.1 & $\mathrm{n} / \mathrm{a}$ & 50.0 & $\mathrm{n} / \mathrm{a}$ & 0.0 & $\mathrm{n} / \mathrm{a}$ \\
\hline Plan to switch herbicides & 15.0 & $\mathrm{n} / \mathrm{a}$ & 23.5 & $\mathrm{n} / \mathrm{a}$ & 66.7 & $\mathrm{n} / \mathrm{a}$ & 0.0 & $\mathrm{n} / \mathrm{a}$ \\
\hline Plan to change herbicide application rates & 10.0 & $\mathrm{n} / \mathrm{a}$ & 11.8 & $\mathrm{n} / \mathrm{a}$ & 33.3 & $\mathrm{n} / \mathrm{a}$ & 100.0 & $\mathrm{n} / \mathrm{a}$ \\
\hline \multicolumn{9}{|l|}{ Plan to use herbicides on } \\
\hline different infestations & 10.0 & $\mathrm{n} / \mathrm{a}$ & 23.5 & $\mathrm{n} / \mathrm{a}$ & 33.3 & $\mathrm{n} / \mathrm{a}$ & 0.0 & $\mathrm{n} / \mathrm{a}$ \\
\hline \multicolumn{9}{|l|}{ Plan to reduce herbicides \& } \\
\hline switch to other controls & 10.0 & $\mathrm{n} / \mathrm{a}$ & 35.3 & $\mathrm{n} / \mathrm{a}$ & 16.7 & $\mathrm{n} / \mathrm{a}$ & 25.0 & $\mathrm{n} / \mathrm{a}$ \\
\hline$(\mathrm{no} .)^{4}$ & $(40)$ & - & (17) & - & (6) & - & (4) & - \\
\hline \multicolumn{9}{|l|}{ If No: } \\
\hline Currently using herbicides & 74.2 & $\mathrm{n} / \mathrm{a}$ & 74.2 & $\mathrm{n} / \mathrm{a}$ & 90.9 & $\mathrm{n} / \mathrm{a}$ & 100.0 & $\mathrm{n} / \mathrm{a}$ \\
\hline Currently using other control methods & 38.0 & $\mathrm{n} / \mathrm{a}$ & 40.0 & $\mathrm{n} / \mathrm{a}$ & 18.2 & $\mathrm{n} / \mathrm{a}$ & 12.5 & $n / a$ \\
\hline Infestations are inaccessible to sprayers & 32.3 & 45.9 & $60.0 * *$ & $50.0 * *$ & 27.3 & 66.7 & 37.5 & 54.6 \\
\hline \multicolumn{9}{|l|}{ Environmental restrictions } \\
\hline prevent herbicide use & $29.0 *$ & $58.9 *$ & $40.0 *$ & $65.5^{\star}$ & $27.3^{*}$ & $85.7^{\star}$ & $37.5^{\star}$ & $82.8^{*}$ \\
\hline Do not have time to spray ${ }^{5}$ & 25.8 & 26.9 & 25.0 & 39.7 & 18.2 & 28.3 & 0.0 & 9.1 \\
\hline Not economical to use herbicides & 25.8 & 43.5 & 30.0 & 41.4 & $18.2 * *$ & $57.1 * *$ & 0.0 & $\mathrm{n} / \mathrm{a}$ \\
\hline \multicolumn{9}{|l|}{ Infestations are too large, herbicides } \\
\hline would be prohibitively expensive & $22.6^{\star}$ & $46.3^{*}$ & 65.0 & 75.9 & $27.3^{*}$ & $71.4^{\star}$ & 12.5 & 45.5 \\
\hline Not convinced herbicides are effective ${ }^{6}$ & 19.4 & 25.3 & 40.0 & 20.7 & 9.1 & 38.1 & 12.5 & 36.4 \\
\hline \multicolumn{9}{|l|}{ Cost share programs are no } \\
\hline longer available & 19.3 & 30.4 & 10.0 & $\mathrm{n} / \mathrm{a}$ & $\mathrm{n} / \mathrm{a}$ & $\mathrm{n} / \mathrm{a}$ & $\mathrm{n} / \mathrm{a}$ & $\mathrm{n} / \mathrm{a}$ \\
\hline Potential damage to nontarget species & 12.9 & $\mathrm{n} / \mathrm{a}$ & 15.0 & 22.4 & 9.1 & 42.9 & 12.5 & 63.6 \\
\hline Cannot afford to purchase herbicides ${ }^{7}$ & 9.7 & $\mathrm{n} / \mathrm{a}$ & 45.0 & $\mathrm{n} / \mathrm{a}$ & $18.1^{\star}$ & $71.4^{\star}$ & $\mathrm{n} / \mathrm{a}$ & $\mathrm{n} / \mathrm{a}$ \\
\hline \multicolumn{9}{|l|}{ Lack equipment, expertise, or } \\
\hline access to certified applicators & 9.7 & 24.1 & 25.0 & 22.4 & $18.1 * *$ & $28.6 * *$ & 0.0 & 18.2 \\
\hline$(\text { no. })^{4}$ & $(30)$ & $(253)$ & (20) & (58) & $(20)$ & $(21)$ & (8) & (10) \\
\hline
\end{tabular}

${ }^{1}$ Only respondents that indicated they were aware of TEAM Leafy Spurge are included in the distribution of responses.

2Source: Sell et al. (1998a), Sell et al. (1998b), Sell et al. (1999).

${ }^{3}$ Source: Sell at al. (1998).

${ }^{4}$ Average number of respondents for each variable.

${ }^{5}$ The public land manager questionnaires were stated in terms of "do not have labor resources to spray."

${ }^{6}$ The public land manager questionnaires were stated in terms of "agency is not convinced herbicides are effective."

${ }^{7}$ The public land manager questionnaires were stated in terms of "agency lacks funding to purchase herbicides."

*Statistically significant between survey periods, $P \leq 0.05$ (Fisher's Exact Test).

${ }^{\star *}$ Statistically significant between survey periods, $P \leq 0.10$ (Fisher's Exact Test).

a statistically significant decline from the $72 \%$ that said there were too many constraints to grazing in 1998-1999. Other constraints were "the infestation was too small" $(36 \%$ of ranchers and $40 \%$ of PLMG), "do not have resources to manage sheep" ( $75 \%$ of LDM), or "land was not suitable for grazing" (36\% of PLMNG). Significantly fewer ranchers in- dicated "sheep grazing is too time consuming" (40\% to $15 \%)$, "sheep will compete with cattle for forage" (37\% to $15 \%)$, "do not know enough about sheep management" (42\% to $11 \%)$, and "sheep grazing is not economical" $(21 \%$ to $6 \%)$. There were no significant differences in the responses of the public land manager study groups. 
Table 5. Impact of TEAM Leafy Spurge Project on weed control strategies using biological control agents; ranchers, local decision makers, and public land managers, 2001, 1998, and 1999.

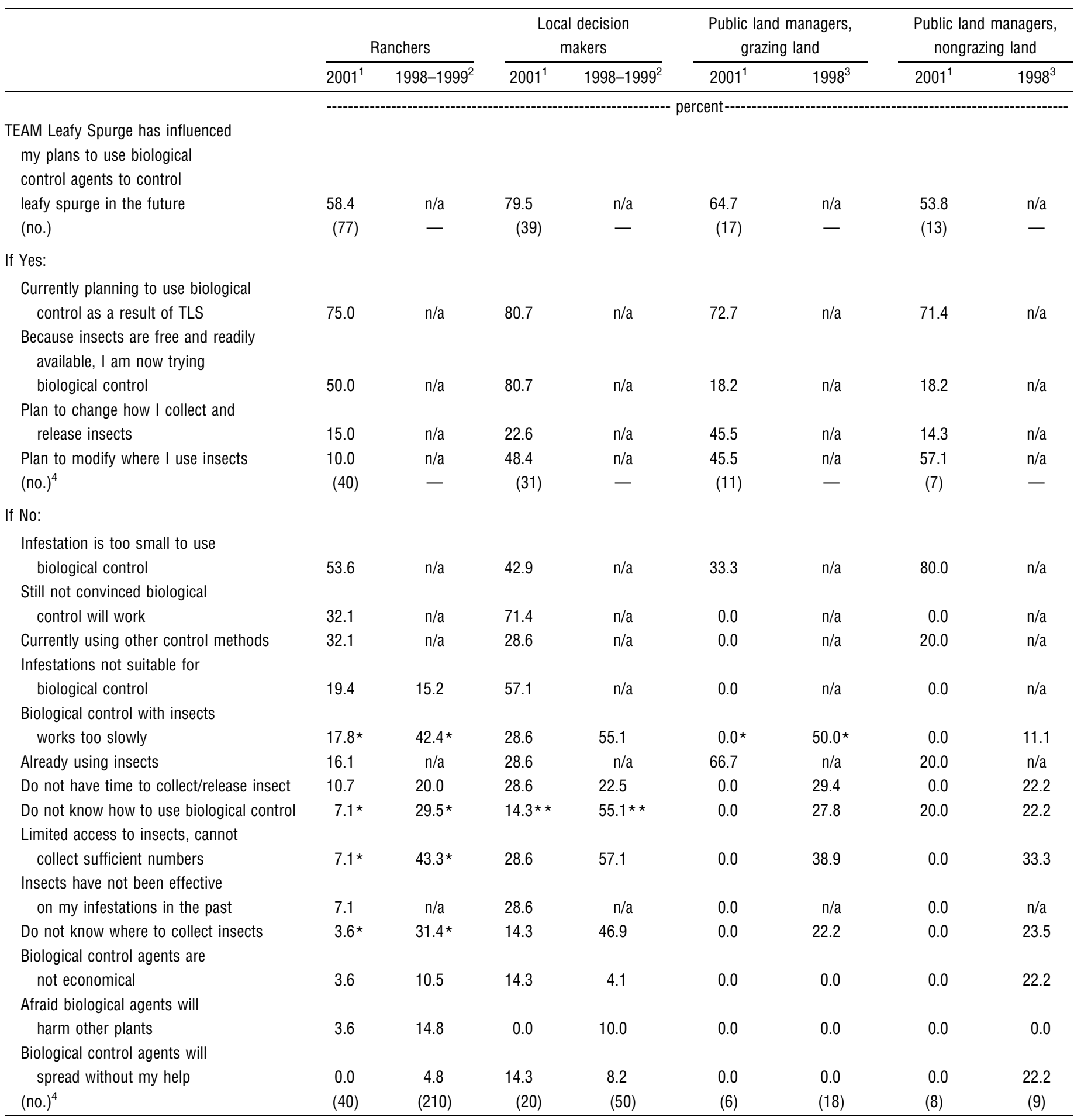

${ }^{1}$ Only respondents that indicated they were aware of TEAM Leafy Spurge are included in the distribution of responses.

${ }^{2}$ Source: Sell et al. (1998a), Sell et al. (1998b), Sell et al. (1999).

${ }^{3}$ Source: Sell at al. (1998b).

${ }^{4}$ Average number of respondents for each variable.

*Statistically significant between survey periods, $P \leq 0.05$ (Fisher's Exact Test).

${ }^{\star \star}$ Statistically significant between survey periods, $P \leq 0.10$ (Fisher's Exact Test).

\section{Key Findings}

Most 2001 survey respondents reported extensive use of biological control and were planning to implement an IPM approach to leafy spurge control. Although biological control and IPM approaches were used extensively by all groups, herbicides continue to be the most widely used control practice. The growing use of biological control and IPM strategies, however, would suggest that landowners and land managers are 
Table 6. Impact of TEAM Leafy Spurge Project on weed control strategies using sheep grazing: ranchers, local decision makers, and public land managers, 2001, 1998, and 1999.

\begin{tabular}{|c|c|c|c|c|c|c|c|c|}
\hline & \multicolumn{2}{|c|}{ Ranchers } & \multicolumn{2}{|c|}{$\begin{array}{l}\text { Local decision } \\
\text { makers }\end{array}$} & \multicolumn{2}{|c|}{$\begin{array}{l}\text { Public land managers, } \\
\text { grazing land }\end{array}$} & \multicolumn{2}{|c|}{$\begin{array}{l}\text { Public land managers, } \\
\text { nongrazing land }\end{array}$} \\
\hline & $2001^{1}$ & $1998-1999^{2}$ & $2001^{1}$ & $\overline{1998-1999^{2}}$ & $2001^{1}$ & $1998^{3}$ & $2001^{1}$ & $1998^{3}$ \\
\hline \multirow{2}{*}{\multicolumn{9}{|c|}{$\begin{array}{l}\text { TEAM Leafy Spurge has influenced } \\
\text { my plans to graze sheep to control }\end{array}$}} \\
\hline & & & & & & & & \\
\hline leafy spurge in the future & 17.1 & $\mathrm{n} / \mathrm{a}$ & 28.6 & $\mathrm{n} / \mathrm{a}$ & 35.3 & $\mathrm{n} / \mathrm{a}$ & 7.7 & n/a \\
\hline (no.) & (73) & - & (35) & - & (17) & - & (13) & - \\
\hline \multicolumn{9}{|l|}{ If Yes: } \\
\hline \multicolumn{9}{|l|}{ Currently using sheep as a } \\
\hline \multicolumn{9}{|l|}{$\begin{array}{l}\text { While grazing works, do not have } \\
\text { resources to implement a }\end{array}$} \\
\hline grazing program & 36.7 & $\mathrm{n} / \mathrm{a}$ & 70.0 & $n / a$ & 66.7 & $n / a$ & 0.0 & $\mathrm{n} / \mathrm{a}$ \\
\hline \multicolumn{9}{|l|}{ Planning to use graze sheep as } \\
\hline a result of TLS & 18.2 & n/a & 40.0 & $\mathrm{n} / \mathrm{a}$ & 33.3 & $\mathrm{n} / \mathrm{a}$ & 100.0 & n/a \\
\hline$(\text { no. })^{4}$ & $(11)$ & - & $(10)$ & - & (6) & - & (1) & - \\
\hline \multicolumn{9}{|l|}{ If No: } \\
\hline \multicolumn{9}{|l|}{ Too many constraints (fencing, } \\
\hline stock, equipment) ${ }^{5}$ & $43.4^{*}$ & $72.2^{\star}$ & $62.5^{\star}$ & $84.2^{\star}$ & 50.0 & 72.0 & 27.3 & 14.3 \\
\hline Infestation is too small & 35.9 & $\mathrm{n} / \mathrm{a}$ & 20.8 & $\mathrm{n} / \mathrm{a}$ & 40.0 & n/a & 9.1 & $\mathrm{n} / \mathrm{a}$ \\
\hline \multicolumn{9}{|l|}{ Do not want another enterprise } \\
\hline on the ranch & 30.2 & $\mathrm{n} / \mathrm{a}$ & 16.7 & $\mathrm{n} / \mathrm{a}$ & $\mathrm{n} / \mathrm{a}$ & $\mathrm{n} / \mathrm{a}$ & $\mathrm{n} / \mathrm{a}$ & n/a \\
\hline Do not like sheep or goats & 28.3 & 35.9 & 54.2 & $\mathrm{n} / \mathrm{a}$ & $\mathrm{n} / \mathrm{a}$ & $\mathrm{n} / \mathrm{a}$ & $\mathrm{n} / \mathrm{a}$ & n/a \\
\hline Do not have resources to manage sheep & 22.6 & 42.4 & 75.0 & $\mathrm{n} / \mathrm{a}$ & 30.0 & $\mathrm{n} / \mathrm{a}$ & 36.4 & n/a \\
\hline Still not convinced sheep grazing will work & 22.6 & $\mathrm{n} / \mathrm{a}$ & 62.5 & $\mathrm{n} / \mathrm{a}$ & 10.0 & $n / a$ & 54.6 & $\mathrm{n} / \mathrm{a}$ \\
\hline \multicolumn{9}{|l|}{ Sheep or goat grazing is too } \\
\hline time consuming & $15.1^{\star}$ & $39.9 *$ & 20.8 & 33.3 & $\mathrm{n} / \mathrm{a}$ & 33.3 & $\mathrm{n} / \mathrm{a}$ & 14.3 \\
\hline Sheep will compete with cattle for forage & $15.1^{*}$ & $37.2^{*}$ & 29.2 & $\mathrm{n} / \mathrm{a}$ & $\mathrm{n} / \mathrm{a}$ & $\mathrm{n} / \mathrm{a}$ & $\mathrm{n} / \mathrm{a}$ & $\mathrm{n} / \mathrm{a}$ \\
\hline \multicolumn{9}{|l|}{ Do not know enough about } \\
\hline sheep management & $11.3^{*}$ & $41.7^{*}$ & 33.3 & 48.2 & 20.0 & 40.3 & 18.2 & 0.0 \\
\hline \multicolumn{9}{|l|}{ Grazing will negatively affect } \\
\hline nontarget species & 11.3 & $\mathrm{n} / \mathrm{a}$ & 20.8 & 22.8 & 10.0 & 19.1 & 18.2 & 28.6 \\
\hline Pasture average is too small to graze sheep & 9.4 & $\mathrm{n} / \mathrm{a}$ & 4.2 & $\mathrm{n} / \mathrm{a}$ & 40.0 & n/a & 18.2 & n/a \\
\hline Sheep grazing is too costly, not economical & $5.7^{*}$ & $21.1^{*}$ & 12.5 & 14.0 & 10.0 & 38.1 & 9.1 & 14.3 \\
\hline Sheep grazing was ineffective in the past & 3.8 & 31.4 & 20.8 & $\mathrm{n} / \mathrm{a}$ & 10.0 & 4.8 & 9.1 & 42.9 \\
\hline Infestation not suitable for sheep grazing & 0.0 & $\mathrm{n} / \mathrm{a}$ & 4.2 & n/a & 0.0 & $\mathrm{n} / \mathrm{a}$ & 36.4 & n/a \\
\hline Agency policy prevent sheep grazing & $\mathrm{n} / \mathrm{a}$ & $\mathrm{n} / \mathrm{a}$ & $\mathrm{n} / \mathrm{a}$ & $\mathrm{n} / \mathrm{a}$ & 10.0 & 9.5 & 9.1 & 28.6 \\
\hline$(\text { no. })^{4}$ & (53) & (223) & (24) & (56) & (10) & $(22)$ & (11) & (7) \\
\hline
\end{tabular}

${ }^{1}$ Only respondents that indicated they were aware of TEAM Leafy Spurge are included in the distribution of responses.

${ }^{2}$ Source: Sell et al. (1998a), Sell et al. (1998b), Sell et al. (1999).

${ }^{3}$ Source: Sell et al. (1998b).

${ }^{4}$ Average number of respondents for each variable.

${ }^{5} 1998$ and 1999 questionnaire worded: "do not have the right equipment."

*Statistically significant between survey periods, $P \leq 0.05$ (Fisher's Exact Test).

${ }^{*}$ Statistically significant between survey periods, $P \leq 0.10$ (Fisher's Exact Test).

expanding their use of new and alternative control practices to complement herbicide treatment programs.

TLS appeared to successfully influence landowners' and land managers' weed control strategies. Relatively high percentages of respondents affirmed that TLS had influenced their weed control practices. This was particularly evident with respect to biological control; $80 \%$ of local decision makers, $65 \%$ of PLMG, $54 \%$ of PLMNG, and $42 \%$ of ranchers indicated that TLS had influenced their plans to use biological agents to control leafy spurge. Results also suggest 
that many of the perceived constraints to using biological control identified in the focus group interviews and the 19981999 survey had moderated. The number of ranchers, local decision makers, and public land managers that indicated they were not using biological control because of lack of information or expertise regarding the control practice (e.g., collect and/or use of insects) was significantly less in 2001 than in 1998-1999.

The TLS project also has been successful in reaching a substantial percentage of its target audience. Thirty-seven percent of ranchers and PLMNG and 90\% of LMD and PLMG attended at least one TLS event or demonstration site or used TLS publications and 76 percent of ranchers that reported leafy spurge on their land attended a TLS event or used a TLS publication. TLS events and publications were well-received with above average ratings from respondents in all study groups. Further, more than $92 \%$ of local decision makers, $71 \%$ of public grazing land managers, and $70 \%$ of ranchers supported extended funding, and a large majority of respondents believe the project has been effective demonstrating and communicating leafy spurge treatment and control options.

Also of note is the apparent change in landowners' philosophy regarding leafy spurge control. The focus group interviews clearly revealed ranchers' overriding sense of frustration in their inability to eradicate leafy spurge. The 2001 survey, however, suggested ranchers were willing to adopt new and integrated control strategies, and some of the more frequently identified constraints to using a given control practice were identified less frequently by respondents. This could very well suggest a shift in management goals from elimination to longterm control, a very positive change in expectations for leafy spurge management.

\section{MANAGEMENT IMPLICATIONS}

Although more options for leafy spurge control are currently available than even just a few years ago, leafy spurge continues to be a problem for ranchers and land managers throughout the survey area. The goal of TLS was to develop and deliver economical, effective leafy spurge control techniques to both private land owners and public land managers. Based on a comparison of the results of the 1998-1999 survey and the results of the 2001 survey, it would appear that the program has successfully reached substantial portions of its target audience and has addressed some of the impediments to control identified in earlier phases of this study. Land owners and land managers have in some instances modified their weed control strategies and adopted new strategies in an effort to address what continues to be a significant issue for not only private land managers' grazing operations, but for public land managers throughout the northern Great Plains.

\section{ACKNOWLEDGMENTS}

This study contributes to an integrated pest management (IPM) research and demonstration project, titled The Ecological Area Wide Management of Leafy Spurge (TEAM Leafy Spurge).
The authors express appreciation to the TEAM Leafy Spurge project (Drs Gerald Anderson and Lloyd Wendel, principal investigators) for their financial support.

\section{LITERATURE CITED}

Bangsund, D. A., F. L. Leistritz, and J. A. Leitch. 1999. Assessing economic impacts of biological control of weeds: the case of leafy spurge in the northern Great Plains of the United States. Journal of Environmental Management 56:35-43.

Bangsund, D. A., D. J. Nudell, R. S. Sell, and F. L. Leistritz. 2001. Economic analysis of controlling leafy spurge with sheep. Journal of Range Management 54:322-329.

Coppock, D. L., AND A. H. BiRKENFELD. 1999. Use of livestock and range management practices in Utah. Journal of Range Management 52:7-18.

Didier, E. A., AND M. W. Brunson. 2004. Adoption of range management innovations by Utah ranchers. Journal of Range Management 57:330-336.

Fernandez-Gimenez, M. E., G. Ruyle, and S. J. McClaran. 2005. An evaluation of Arizona Cooperative Extension's Rangeland Monitoring Program. Rangeland Ecology \& Management 58:89-98.

Hodur, N. M., F. L. Leistritz, and D. A. Bangsund. 2002a. Ranch operators' perceptions of leafy spurge management and evaluation of the TEAM Leafy Spurge Project. Agribusiness \& Applied Economics Report No. 493. Fargo, ND: Department of Agribusiness and Applied Economics, North Dakota State University. Available at: http://agecon.lib.umn.edu. Accessed 25 July 2006.

Hodur, N. M., F. L. Leistritz, and D. A. Bangsund. 2002b. Perceptions of leafy spurge and evaluation of the TEAM Leafy Spurge Project by public land managers, local decision makers, and ranch operators. Agribusiness \& Applied Economics Report No. 499. Fargo, ND: Department of Agribusiness and Applied Economics, North Dakota State University. Available at: http:// agecon.lib.umn.edu. Accessed 25 July 2006.

Kreuter, U. P., H. E. Amestoy, D. N. Ueckert, and W. A. McGinty. 2001. Adoption of brush busters: results of Texas County extension survey. Journal of Range Management 54:630-639.

LE, C. T. 1948. Applied categorical data analysis. New York, NY: John Wiley \& Sons. $287 \mathrm{p}$.

Leistritz, F. L., D. A. Bangsund, and N. M. Hodur. 2004. Assessing the economic impact of invasive weeds: the case of leafy spurge (Euphorbia esula). Weed Technology 18:1392-1395.

LYM, R. G. 2005. Integration of biological control agents with other weed management technologies: success from the leafy spurge (Euphorbia esula) IPM program. Biological Control 35:366-375.

LyM, R. G., AND C. G. Messersmith. 1994. A decade of herbicide treatments controlled leafy spurge. North Dakota Farm Research 50:9-12.

LYM, R. G., K. K. SEDIVIC, AND D. R. KIRBY. 1997. Leafy spurge control with angora goats and herbicides. Journal of Range Management 50:123-128.

LYM, R. G., AND R. K. ZoLLINGer. 1995. Integrated management of leafy spurge. Extension Publication W-866. Fargo, ND: North Dakota State University Extension Service. $7 \mathrm{p}$.

Peterson, R., and D. L. Coppock. 2001. Economics and demographics constrain investment in Utah private grazing lands. Journal of Range Management 54:106-114.

Rowan, R. C., AND L. D. White. 1994. Regional differences among Texas rangeland operators. Journal of Range Management 47:338-343.

SAS Institute, Inc. 2004. SAS OnlineDoc 9.1.3. Cary, NC: SAS Institute, Inc.

SchmidT, C. H. 1998. Leafy spurge news. XXI (3). Fargo, ND: North Dakota State University Extension Service. $8 p$.

Sell, R. S., D. A. Bangsund, F. L. Leistritz, and D. Nudell. 1998a. Ranch operators' perceptions of leafy spurge. Agricultural Economics Report No. 400. Fargo, ND: Department of Agricultural Economics, North Dakota State University. Available at: http://agecon.lib.umn.edu. Accessed 25 July 2006.

Sell, R. S., D. A. Bangsund, F. L. Leistritz, and D. Nudell. 1998b. Perceptions of leafy spurge by public land managers, local decision makers, and ranch operators. Agricultural Economics Report No. 406. Fargo, ND: Department of 
Agricultural Economics, North Dakota State University. Available at: http:// agecon.lib.umn.edu. Accessed 25 July 2006.

Sell, R. S., D. A. Bangsund, and F. L. Leistritz. 1999a. Perceptions of leafy spurge by ranch operators and local decision makers: an update. Agricultural Economics Statistical Series Report No. 56. Fargo, ND: Department of Agricultural Economics, North Dakota State University. Available at: http:// agecon.lib.umn.edu. Accessed 25 July 2006.
SelL, R. S., D. A. Bangsund, and F. L. Leistritz. 1999b. Euphorbia esula: perceptions by ranchers and land managers. Weed Science 47:740-749.

Sell, R. S., D. A. Bangsund, and F. L. Leistritz. 2000. Impediments to controlling leafy spurge in the northern Great Plains. Agricultural Economics Miscellaneous Report No. 185. Fargo, ND: Department of Agricultural Economics, North Dakota State University. Available at: http://agecon.lib. umn.edu. Accessed 25 July 2006. 